DOI: $10.7242 / 1998-2097 / 2018.4 .12$

УДК $321.6 / .8+324$

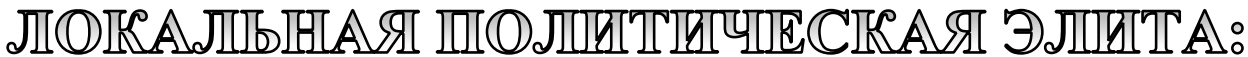

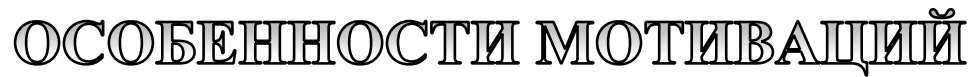

Т.Б. Витковская, Пермский федеральный исследовательский центр УрО РАН

В статье предпринята попытка анализа основных компонентов мотивационного профиля и ценностной сфреры ключевых представителей локальной политической элиты - глав муниципалитетов и депутатов представительных органов МСУ. Рассмотрены мотивы кандидатов на должность главы и действующих глав муниципалитетов. Показано, что ведущими мотивами являются карьерный мотив и мотив достижения власти. Рассмотрены различные мотивы муниципальных депутатов, побуждающие их избираться в местные собрания: формирование положительной репутации, приобретение престижного статуса, лоббирование бизнес-интересов и прочие. Отдельно выделены мотивы депутатов в рамках альтруистической логики: помощь муниципальному образованию, местному сообществу, бюджетным учреждениям, решение острых социальных проблем и т.д. Объясняется, как длительность пребывания «у власти» меняет картину мотиваций представителей локальной элиты. Выделено общее и особенное в мотивациях местных политиков и предпринимателей; указаны мотивы предпринимателей, претендующих на депутатские мандаты или муниципальные должности. Названы социально одобряемые и неодобряемые мотивы.

Ключевые слова: локальная элита, локальная политика, мотивационный профиль, глава МСУ, депутат представительного органа МСУ.

На уровне муниципальных образований в современной России политические отношения в значительной степени персонифицированы и ключевые политические институты неотделимы от личностей политиков. Это определяет актуальность исследования мотиваций и ценностей ведущих местных политиков и других представителей локальной элиты. В данной статье предпринята попытка анализа особенностей мотиваций глав муниципалитетов и депутатов представительных органов МСУ.

Эмпирической основой исследования стали интервью, проведенные в четырех муниципальных образованиях Пермского края и Свердловской области. В статье приводятся цитаты из интервью с представителями местных политических элит (депутаты представительных органов МСУ, работники муниципальных администраций) и примеры из политической практики данных муниципальных образований.

\section{Корпус глав муниципалитетов: мотивации местных лидеров}

На сегодняшний день представители локальных элит оценивают позицию главы муниципалитета как самую выгодную, 
обеспечивающую большую, чем все другие позиции, власть в границах муниципального образования и влияние за его пределами. Такая оценка представляется вполне справедливой. Прежде всего, влияние главы обеспечено широким кругом его официальных полномочий как высшего должностного лица на этом уровне публичной власти. Так, он участвует в законотворческой работе, решении вопросов местного значения, представляет муниципалитет в отношениях с другими институциями и осуществляет отдельные государственные полномочия [8]. Кроме того, административные возможности главы муниципального образования на практике шире его должностных полномочий, он может задействовать ресурсы других органов власти (в том числе регионального уровня) и различных контролирующих организаций [5, с. 118-119].

Таким образом, пост главы муниципалитета может быть целью для претендентов, имеющих разные мотивы, однако наиболее распространенными среди них остаются карьерный мотив и мотив достижения власти (которые оказываются связанными, когда речь идет о профессиональных политиках). Для многих претендентов на пост главы муниципалитета, как и для всех инкумбентов, победа на выборах означает успешность политической карьеры, которую они строят. Для местного политика этот пост - верхняя ступень карьерной лестницы, выше подняться нельзя (возможности муниципальных политиков на региональном политическом поле крайне ограниченны).

Для многих политиков борьба за руководящую позицию в системе МСУ оказывается и борьбой с конкурентами, политическими оппонентами, а победа в этой борьбе становится не только карьерным достижением, но и личным успехом. Например, в городе Кунгуре - небольшом торговом городе в Пермском крае - два местных политика поочередно сменяли друг друга на посту главы (конкурировали за должность в ходе избирательных кам- паний 2004, 2008, 2013 годов). Каждые выборы мэра в городе на протяжении десятилетия были также их личным состязанием, и результаты выборов определяли их политические роли (действующий глава города / лидер оппозиции) и, в определенной степени, социальные роли (после поражений один занимался собственным бизнесом, другой - работал в сфере медиа). К изначальной мотивации каждого из политиков: один был, по собственному определению, «политиком-самоучкой» [1] и нацелен на политическую карьеру, второй, кроме политических амбиций, имел интерес в развитии своего бизнеса, добавлялись азарт борьбы и жажда реванша, которые росли с каждым выборным циклом [7].

Для глав муниципальных образований власть может быть не только самозначимой целью, но и инструментом, который позволяет эффективно реализовать их интересы, в том числе бизнес-интересы. Претенденты на высший муниципальный пост могут иметь собственный бизнес, занимающие данный пост не могут вести предпринимательскую деятельность, но также могут иметь интересы в сфере местного бизнеса, реализуемые через доверенных лиц. Широкий круг полномочий главы и административные возможности, которые обеспечивает занятие высшей муниципальной должности, позволяют успешно реализовывать интересы собственного бизнеса или бизнеса партнеров, успех которого приносит дивиденды. В случаях, когда глава использует упомянутые возможности, его мотивация оказывается в целом более сложной, чем мотивация бизнесмена, но они имеют много сходных побудительных мотивов.

Интересны мотивы глав муниципальных образований, которые ранее занимали руководящие должности в силовых структурах. Они составляют немногочисленную группу местных лидеров, для которых власть является не способом достижения различных целей (которые варьируются в зависимости от вектора 
карьеры), но именно самозначимой целью. Их мотивация на достижение и удержание власти определена прошлым профессиональным опытом. Как правило, их профессиональная деятельность была связана с реализацией власти в той или иной форме и предполагала работу в условиях жесткой властной иерархии.

Сохранение власти может стать значимым (и самозначимым) мотивом для главы, долгое время (три и более сроков полномочий) занимавшего высший муниципальный пост. Это также предопределено позицией, предполагающей обладание властью и отправление власти. Не имея возможности претендовать на переизбрание, глава, руководивший муниципалитетом долгое время, может, тем не менее, претендовать на сохранение реальной власти (не в полном объеме и без официальных атрибутов). Показательны ситуации, когда главы выбирали «преемников» и помогали их избранию. Например, в Усольском районе - благополучной территории в Пермском крае, бывший глава, руководивший муниципалитетом почти два десятилетия (с 1996 по 2013 годы), в течение последнего срока полномочий разработал и реализовал сложную схему расстановки своих представителей на ключевые муниципальные позиции: главы района, главы городского поселения, глав ряда поселений в составе района [4]. Он оставил пост главы муниципалитета, но сохранил возможность влиять на работу администраций района и города, удерживая контроль над локальной политикой.

Вместе с тем для глав муниципалитетов (как и других местных политиков) могут быть значимы мотивы повышения социального статуса и материального благополучия. Подобные мотивы не артикулируются, поскольку не являются социально приемлемыми.

Можно предположить, что в отдельных случаях занимающие пост главы, как и претендующие на него, руководствуются корыстными мотивами. Широкий круг официальных полномочий и реальных возможностей высшего должностного лица, а также коррупционный потенциал действующей системы муниципального управления, в которой остается много нерешенных проблем, оставляют шансы для реализации корыстных интересов.

\section{Муниципальный депутатский корпус: социальный и мотивационный профиль \\ Интерес кандидатов в депутаты} к работе в составе представительного органа МСУ обусловлен его полномочиями и ролью, которую играют муниципальные депутаты в местном сообществе.

Мандат депутата обеспечивает его обладателю особый статус: с одной стороны, депутат является представителем власти, с другой - представителем местного сообщества во власти. Оценка депутата как «народного избранника» характерна для восприятия депутатов электоратом: депутат говорит о коллегах «когда к ним приходят на прием, к ним приходят как к представителям от народа, а не как к власти административной» [2]. Благодаря подобному взгляду на роль муниципального депутата статус депутата не только престижен, но и может повысить узнаваемость, улучшить репутацию и поднять доверие к тому, кто его приобрел. Занятие данной позиции может повысить социальный статус кандидата, получившего мандат, вне зависимости от его бэкграунда: если ранее он занимался политической или общественной деятельностью, мандат легитимирует его амбиции, если до избрания не участвовал в общественно-политической жизни открывает новые карьерные перспективы и закрепляет новую социальную роль.

Занятие депутатского кресла может быть стартом политической карьеры или значимым ее этапом. Вместе с тем не только публичные политики или общественные деятели демонстрируют интерес к участию в работе представительного органа местной власти; более того, не они составляют основную долю претендентов на депутатские мандаты. 
Заинтересованность в депутатском мандате зачастую показывают местные бизнесмены, при том что они могут не интересоваться общественной или иной деятельностью, не связанной с предпринимательской. Их интерес обусловлен полномочиями муниципального депутатского корпуса. Он ведет законотворческую деятельность, что обеспечивает депутатам возможность влиять на повестку. Не менее важно, что в компетенции депутатского корпуса находится утверждение муниципального бюджета и местных налогов, депутаты распоряжаются муниципальным имуществом, в том числе земельными участками, и контролируют работу муниципальных предприятий [8].

Указанные компетенции формируют лоббистский потенциал представительного органа МСУ. Мотивы бизнесменов, имеющих депутатские мандаты, напрямую связаны с предпринимательской деятельностью, и лоббирование интересов бизнеса через орган публичной власти остается их основным мотивом. Цели, которые они преследуют и надеются реализовать, имея статус депутата, разнообразны: от приобретения новых социальных связей (в новом социальном кругу) до улучшения собственной репутации и репутации своего бизнеса, от снижения административных барьеров в предпринимательной деятельности до получения разного рода льгот.

В составе представительных органов МСУ повсеместно присутствуют так называемые «бюджетники» - руководители и сотрудники бюджетных учреждений, представляющие сферы образования, здравоохранения и культуры. Широкая представленность «бюджетников» в депутатских собраниях показывает их заинтересованность в участии в работе по решению вопросов местного значения. При этом их побудительные мотивы отличаются от мотивов предпринимателей, претендующих на депутатские мандаты. Соответственно, отличается и направленность работы, и сферы приложения основ- ных усилий депутатов из данных категорий. Представители учреждений социального профиля, в силу их профессионального опыта, активнее участвуют в решении социальных проблем на территории, продвигая их в повестке. Они в большей степени ориентированы на общественное благо, как они его понимают (зачастую, связывая именно с развитием социальной сферы) и на проблемы, общие для большей части локального сообщества.

Мотивы «бюджетников» при том что оказываются не только декларируемыми, но и реально действующими, являются социально одобряемыми, что выступает одной из основных составляющих их высокого электорального потенциала. Вместе с тем ожидания населения могут мотивировать активных работников социальной сферы к выдвижению в депутаты. Муниципальный депутат, занимающая пост директора школы, так говорит о своих мотивах: «Очень многие люди оказывали свое доверие. Если люди верят, нужно ресурс этот использовать. А каких-то других позывов, честно говоря, ... не было, то есть ни карьерных, ни взаимовыгоды какой-то, ни личной вылодыр» [3]. Карьерная мотивация не характерна для представителей бюджетных учреждений. Отдельные «бюджетники», конечно, могут быть ориентированы на карьеру в своей сфере, но не связывают депутатскую деятельность и карьерную перспективу. Директора бюджетных учреждений также могут быть ориентированы на помощь организациям, которыми руководят, или сферам, которые представляют (как правило, образованию или здравоохранению). Муниципальный депутат, дважды избиравшаяся в представительный орган, прямо называет этот мотив: «Являясь директором школь, я прекрасно понимаю, что нахождение непосредственно «внутри» ... способствует развитию нашего образовательного учреждения» [3].

Предприниматели, имеющие мандат депутата, также могут проявлять заинте- 
ресованность в решении проблем территории, в том числе актуальных социальных проблем, но помощь локальному сообществу не является для них основным мотивом или мотивом, побудившим их участвовать в выборах. Актуализация данного мотива зачастую происходит, когда предприниматель работает в составе представительного органа власти в течение нескольких созывов.

Мотивы и цели отдельных депутатов отражаются на направленности и результатах работы представительного органа в целом. Распространенность мотива помощи сообществу или реализации общественного блага помогает депутатскому корпусу работать в направлении решения стратегических вопросов местного значения и не сосредотачиваться на частных проблемах. Бывший заместитель главы района из города Чусового - муниципального образования со статусом территории опережающего развития в Пермском крае, так говорит о мотивах депутатов и потенциале территории: «Очень важно присутствие на территории мини-лидеров, людей, которые проявляют иниичиативу, что-то хотят сделать для развития территории, стремятся $\kappa$ конкретному результату. Они - та сила, которая инициирует сочиальные инициативы, организует общественность. Чем меньше таких людей, тем меньше территориальный потенциaл» [6, с. 136]. Вместе с тем слабость этого мотива в депутатской среде зачастую позволяет личным интересам депутатов формировать повестку представительного органа местного самоуправления.

\section{Выводы}

Для ряда кандидатов в муниципальные депутаты и кандидатов на пост главы муниципалитета выдвижение является ответом на ожидания населения, хотя кандидаты имеют и личные мотивы. Это верно для кандидатов, которые ранее занимались общественной деятельностью, некоторых профессиональных политиков (включая глав-инкумбентов с высоким уровнем электоральной поддержки) и представителей бюджетных учреждений социальной сферы. При этом социальные ожидания, конечно, не имеют принудительной силы, но важны, поскольку обеспечивают претендентам на власть легитимность в глазах местного сообщества. Кроме того, у некоторых кандидатов (для которых значимо личное переживание) они резонируют с личностной мотивацией.

Для занимающих ключевые муниципальные посты важно достижение частных интересов, которые варьируются от доступа к власти до интересов материальных. При этом в числе мотивов может быть и достижение общественного блага. Мотив помощи локальному сообществу или территории для одних кандидатов является побудительным, для других остается только декларируемым. Личные приоритеты и ценности политиков определяют, какие мотивы оказываются ведущими.

В целом, мотив достижения и удержания власти значим прежде всего для глав муниципалитетов, поскольку данный пост обеспечивает реализацию этого устремления. Для муниципальных депутатов наиболее значимы лоббистские возможности представительного органа (если они занимаются предпринимательской деятельностью) и его компетенции по решению вопросов местного значения (если они занимаются общественной деятельностью или представляют социальную сферу).

\footnotetext{
Библиографический список

1. Агитационные материалы кандидата на должность главы г. Кунгура Пермского края Махмудова А.Н., избирательная кампания - 2008.

2. Архив автора. Интервью №1 (взято Витковской Т.Б., 2018 г.).

3. Архив автора. Интервью №2 (взято Витковской Т.Б., 2018 г.).

4. Архив автора. Интервью №3 (взято Махмудовой Е.А., 2013 г.).
} 
5. Витковская Т.Б., Рябова О.А. Моногорода Среднего Урала: локальные элиты и политические процессы. - Екатеринбург: РИО УрО РАН, 284 с.

6. Войцехов С.С. Выступление на экспертном круглом столе (расшифровка стенограммы) // Современный город: власть, управление, экономика. - Вып. VI (2016). - С. 118-142.

7. Махмудова Е.A. Главы МСУ и модели власти в Пермском крае (рукопись, 2013 г., архив автора).

8. Федеральный закон от 06.10.2003 г. № 131-Ф3 «Об общих принципах организации местного самоуправления в Российской Федерации» (в ред. от 03.08.2018) // Собр. законодательства РФ, № 40, 2003. ст. 3822 .

\title{
LOCAL POLITICAL ELITE: THE SPECIFICS OF MOTIVATION
}

\author{
T.B. Vitkovskaya \\ Perm Federal Research Center UB RAS
}

The article attempts to analyze the main components of the motivational profile and the value sphere of key representatives of local political elite - the heads of municipalities and municipal deputies. The motives of the candidates for the position and the acting heads of municipalities are considered. It is shown that the leading motives are the career motive and the motive to gain power. The various motives of municipal deputies that encourage them to be elected to local assemblies are considered: the formation of positive reputation, the acquisition of a prestigious status, lobbying for business interests and others. The motives of the deputies within the framework of altruistic logic are highlighted: helping the municipality, the local community, some budget institutions, solving acute social problems, etc. The article also explains how the period of staying in power changes the motivation of representatives of the local elite. General and particular features in the motivations of local politicians and entrepreneurs are shown; the motives of entrepreneurs applying for deputy or municipal positions are indicated. Socially approved and disapproved motives are named.

Keywords: local elite, local politics, motivational profile, the head of the local government, municipal deputy.

\section{Сведения об авторе}

Витковская Татьяна Борисовна, кандидат политических наук, научный сотрудник отдела по исследованию политических институтов и процессов, Пермский федеральный исследовательский центр УрО РАН (ПФИЦ УрО РАН), 614900, г. Пермь, ул. Ленина, 13А; e-mail: vit.tatiana@gmail.com 